\title{
The activation of protease-activated receptor 1 mediates proliferation and invasion of nasopharyngeal carcinoma cells
}

\author{
QINGYAO ZHU ${ }^{1}$, JIANCHAO LUO ${ }^{1}$, TAO WANG ${ }^{2}$, JINGHUA REN $^{2}, \mathrm{KAI} \mathrm{HU}^{3}$ and GANG WU ${ }^{2}$ \\ ${ }^{1}$ Department of Oncology Radiotherapy, Henan Provincial People's Hospital, Zhengzhou 450003; \\ ${ }^{2}$ Cancer Center, Union Hospital, Tongji Medical College, Huazhong University of Science and Technology, Wuhan 430022; \\ ${ }^{3}$ Department of Radiation Oncology, The First Affiliated Hospital of Guangxi Medical University, Nanning 530021, P.R. China
}

Received January 30, 2012; Accepted March 19, 2012

DOI: $10.3892 /$ or.2012.1802

\begin{abstract}
Protease-activated receptor 1 (PAR-1) is a G-coupled membrane protein, which is involved in physiological and malignant invasion processes. It is activated by serine proteases such as thrombin through a unique form or by specific synthetic peptides. In this study, we determined the expression of PAR-1 in five nasopharyngeal carcinoma (NPC) cell lines with different characteristics of invasiveness and metastasis, and found that the levels of PAR-1 expression were higher in invasive or metastatic cell lines than those in low invasive or metastatic ones. Of the five NPC cell lines, CNE1-LMP1 cells had the highest expression levels of PAR-1, which was mainly distributed at the membrane and in the cytoplasm of tumor cells. Further study showed that the thrombin receptor synthetic activating peptide SFLLRN could stimulate the growth of CNE1-LMP1 cells in a dosedependent manner. However, thrombin itself had a dual effect on the proliferation of NPC cells. Concentrations of thrombin in the range of $0.1-0.5 \mathrm{U} / \mathrm{ml}$ promoted cell growth, but concentrations higher than $0.5 \mathrm{U} / \mathrm{ml}$ impaired cell growth. Moreover, thrombin and SFLLRN also enhanced the invasive capabilities of CNE1-LMP1 cells in vitro, and this was partly due to enhancing the activities of MMP-2 and MMP-9. Our findings suggest that PAR-1 may contribute to the growth and invasive potential of NPC cells.
\end{abstract}

\section{Introduction}

Coagulation disorders have been widely described in various cancer patients. Many studies have found that malignant cells could activate the coagulation system and create a hyperco-

Correspondence to: Dr Tao Wang, Cancer Center, Union Hospital, Tongji Medical College, Huazhong University of Science and Technology, Wuhan 430022, P.R. China

E-mail: hustwangtao@hotmail.com

Key words: nasopharyngeal carcinoma, protease-activated receptor 1, thrombin, proliferation, invasion, metastasis agulable state, and in turn a variety of active molecules of coagulation system could contribute to pathogenesis of carcinoma (1-3). Thrombin is one of these active molecules (4).

Thrombin is a multifunctional serine protease involved in a variety of biologic function, including blood coagulation, platelet aggregation, and cell proliferation (5). These effects of thrombin were achieved mainly through thrombin receptors on the cell membrane. Protease-activated receptor 1 (PAR-1), also known as thrombin receptor 1, which is one of the major thrombin receptors, mediates at least partly biological effects of thrombin. Human PAR-1 gene is located on chromosome $5 q 13$ and encodes a $66-\mathrm{kDa}$ single polypeptide that belongs to the superfamily of the $G$ protein-coupled receptors. However, unlike other cellular membrane receptors, PAR-1 does not simply form a ligand-receptor complex for activation. Instead, the receptor binds serine proteases such as thrombin serves as a substrate for proteolytic cleavage between the Arg41 and Ser42 residues in its N-terminal extracellular domain, and the tethered ligand functions as a new receptor agonist resulting in an irreversibly activated form of cell surface protein and transducts a substantial network of signaling pathways. In addition to proteolytic activation, PAR-1 can also be activated by synthetic peptides designed corresponding to its tethered ligand, and this is independent of receptor proteolysis $(6,7)$.

Apart from its physiological function role in thrombosis, inflammation and vascular biology, up to now, accumulating evidence suggests that PAR-1 plays an important role in tumor growth and metastasis (8). It has been reported that PAR-1 was expressed highly in many types of cancer, such as breast cancer (9), malignant melanoma (10), prostate cancer (11), colon cancer (12), lung cancer (13), oral squamous cell carcinoma (14), esophageal cancer (15), and renal cell carcinoma (16). Early study by Even-Ram et al (9) demonstrated that PAR-1 expression levels were correlated with degree of invasiveness in both primary breast tissue specimens and established cancer cell lines. Further study indicated PAR-1 was both required and sufficient to promote growth and invasion of breast carcinoma cells in a xenograft model (17). Similar conclusion was also reached in human prostate cancer $(11,18,19)$. In human colon cancer cells, aberrant expression and activation of PAR-1 could induce cell proliferation, matrix adhesion, motility and migration $(12,20)$. Furthermore, the in vitro study demonstrated PAR-1 was also a rate-limiting 
factor for the process of thrombin enhanced experimental pulmonary metastasis from a mouse melanoma cell line (21). The PAR-1 function in malignancy is additionally supported by the identification of PAR-1 gene as a potent oncogene in a cDNA expression library screen for genes that induce focus forming activity and tranformation in NIH-3T3 cells (22). Moreover, more recent studies showed that PAR-1 expression was closely associated with the clinical stage of cancer patients and thus PAR-1 might be a negative indicator of prognosis for cancer patients (23-26).

Nasopharyngeal carcinoma (NPC) has a high incidence in China, and the significant alteration of blood coagulation pathway has been observed in NPC patients (27). In addition, our previous study indicated PAR-1 was expressed highly in NPC tissue (28). But so far, the role of PAR-1 and thrombin in NPC is barely known. This study aimed to determine PAR-1 expression levels in five different NPC cell lines and to explore the potential function of PAR-1 and thrombin in NPC cells.

\section{Materials and methods}

Cell lines and cell culture. The five NPC cell lines (CNE1, CNE1-LMP1, CNE2, SUNE1-5-8F and SUNE1-6-10B) were obtained from Xiang Ya Central Experiment Laboratory, Central South University (Changsha, China). They were chosen because of their varying characteristics of invasiveness and metastasis. CNE1 is a well differentiated cell line. CNE1-LMP1 is a cell line which was stably transfected with the gene of latent membrane protein-1 (LMP1), and it has been confirmed to be more invasive and metastatic than CNE1 cell line (29). CNE2 is a poorly differentiated cell line. SUNE1$5-8 \mathrm{~F}$ cell line has high tumorigenic and metastatic potential. In contrast, SUNE1-6-10B cells possess low tumorigenicity and lack metastatic capability (30). The cells were cultured in RPMI-1640 medium (Gibco, Rockville, USA) supplemented with $10 \%$ newborn calf serum (Gibco) in a humidified atmosphere of $5 \% \mathrm{CO}_{2}$ at $37^{\circ} \mathrm{C}$.

$R N A$ isolation, $c D N A$ synthesis and relative quantitative realtime PCR. The total RNA from five different NPC cell lines was extracted using TRIzol Reagent (Invitrogen, Carlsbad, CA, USA) according to the manufacturer's instructions and stored at $-70^{\circ} \mathrm{C}$. cDNA was synthesized from $2 \mu \mathrm{g}$ of total RNA using ReverTra Ace ${ }^{\mathrm{TM}}$ kit (Toyobo, Osaka, Japan). The following primer sequences were used in real-time PCR: the PAR-1 gene sense: 5'-AAATGAAGGTCAAGAAGCCG-3', and anti-sense: 5'-CAAACTGCCAATCACTGCC-3'; the $\beta$-actin gene sense: 5'-TCACCCACACTGTGCCCAT-3', and anti-sense: 5'-ATGTCACGCACGATTTCCC-3'. $\beta$-actin was used as a control. Real-time PCR assay was conducted with a Mx3000P thermocycler (Stratagene, La Jolla, CA, USA) using a $25 \mu \mathrm{l}$ reaction volume consisting of $10 \mu \mathrm{l}$ of SYBR-Green Real-time PCR Master Mix (Toyobo, Osaka, Japan), $0.8 \mu 1$ of $10 \mu \mathrm{M}$ primers (each), $2 \mu \mathrm{l}$ of cDNA and $6.4 \mu \mathrm{l}$ of sterile milli-Q water. And reaction conditions were as follows: an initial incubation at $95^{\circ} \mathrm{C}$ for $30 \mathrm{sec}$, followed by 40 cycles of $95^{\circ} \mathrm{C}$ for $5 \mathrm{sec}, 60^{\circ} \mathrm{C}$ for $20 \mathrm{sec}$ and $75^{\circ} \mathrm{C}$ for $15 \mathrm{sec} .2^{-\Delta \Delta \mathrm{Ct}}$ method was used to analyze relative expression levels of PAR-1 mRNA, which was previously described by Livak and Schmittgen (31).
Protein extraction and western blot analysis. The cells were harvested by scraping cells from culture dishes and then collected by centrifugation. The cells were lysed in RIPA buffer $(10 \mathrm{mmol} / 1$ Tris, $\mathrm{pH} 7.4 ; 150 \mathrm{mmol} / \mathrm{l} \mathrm{NaCl} ; 1 \%$ Triton $\mathrm{X}-100 ; 1 \%$ deoxycholic acid; $0.1 \% \mathrm{SDS} ; 5 \mathrm{mmol} / \mathrm{l}$ EDTA, $\mathrm{pH} 8.8 ; 1 \mathrm{mmol} / 1 \mathrm{PMSF} ; 10 \%$ protease inhibitor cocktail; $1 \%$ dithiothreitol) for $30 \mathrm{~min}$ at $4^{\circ} \mathrm{C}$. The lysates were subjected to centrifugation at $12,000 \mathrm{rpm}$ at $4^{\circ} \mathrm{C}$ for $30 \mathrm{~min}$. The protein concentration was measured using $\mathrm{BCA}$ assay according to the manufacturer's instructions (Beyotime, Shanghai, China). Fifty micrograms of total protein for each sample were separated by $10 \%$ gradient SDS-PAGE and then transferred onto polyvinylidene difluoride membrane (Millipore, Billerica, MA, USA) for western blot analysis. Each membrane was subsequently blocked with 5\% dry no-fat milk in TBS-T (Trisbuffered saline and $2.5 \%$ Tween-20) and then incubated with primary antibodies (Santa Cruz Biotechnology, Santa Cruz CA, USA). The membranes were washed with TBS-T and incubated with secondary antibodies conjugated with peroxidase, and the signal was detected using the chemiluminescent detection system (Pierce, Rockford, IL, USA) according to the manufacturer's instructions. $\beta$-actin protein level was used as a control.

Immunofluorochemistry. CNE1-LMP1 cells were plated on glass coverslips in a 6 -well plate $\left(1 \times 10^{4}\right.$ cells per well) and were grown in RPMI-1640 medium containing $10 \%$ newborn calf serum for 12-24 h to ensure adherence. Medium was aspirated and the cells were fixed with $4 \%$ paraformaldehyde in PBS for $20 \mathrm{~min}$ and then rinsed 3 times with PBS (phosphate-buffered saline) for $5 \mathrm{~min}$ each time. The fixed cells were permeabilized with $0.1 \%$ Triton X-100 (Amresco, Solon, OH, USA) and then rinsed 3 times with PBS for 10 min each time. All the cells were blocked using 4\% BSA (bovine serum albumin) in PBS for $1 \mathrm{~h}$, and then rinsed with PBS for $5 \mathrm{~min}$. Primary antibodies, anti-human thrombin receptor mouse monoclonal $\mathrm{IgG} 1$, were incubated with the cells overnight at $4^{\circ} \mathrm{C}$. The coverslips were washed 3 times in PBS for 10 min each time and incubated with secondary antibody, goat anti-mouse IgG each conjugated with CY-3 (Proteintech Group Inc., Chicago, IL, USA), for $1 \mathrm{~h}$ in the dark at room temperature. Coverslips were washed three times with PBS and then the nuclei were stained with Hoechst (Sigma, St. Louis, MO, USA) for $10 \mathrm{~min}$. Finally the labeled cells were visualized and photographed by a Leica TCS SP2 laser scanning confocal microscope.

Cell growth assay (MTT). CNE1-LMP1 cells were plated at a concentration of $3 \times 10^{3}$ cells/well into 96 -well plates in quintuplicate. Twenty-four hours later, the medium was replaced with $1 \%$ serum medium containing varying concentrations of thrombin (Sigma) or PAR-1 synthetic activating peptide SFLLRN (synthesized by Wuhan NewEast Biosciences Co., Ltd., Wuhan, China). After incubation for 48 or $96 \mathrm{~h}, 10 \mu \mathrm{l}$ of 3-(4,5-dimethylthiazol-2-yl)-2,5-diphenyltetrazolium bromide (MTT) solution (5 $\mathrm{mg} / \mathrm{ml}$ in PBS) was added to each well, and the incubation was carried out for $4 \mathrm{~h}$. Then the supernatant was discarded, and the crystal products were eluted with $100 \mu \mathrm{l}$ DMSO (Amresco). A colorimetric evaluation was performed using a spectrophotometer (BioTek, Seattle, WA, USA) at a 


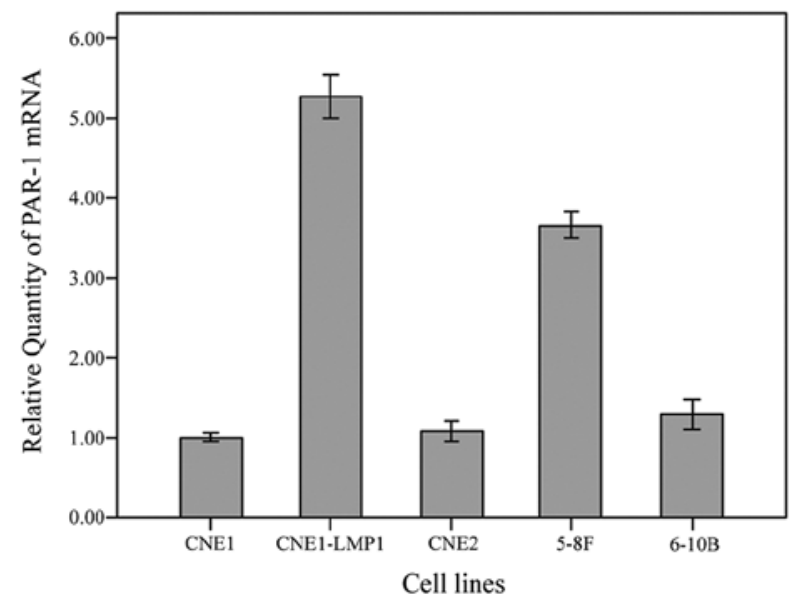

Figure 1. Semiquantitative analysis of PAR-1 mRNA expression by real-time PCR in five NPC cell lines. Expression level of PAR-1 mRNA in CNE1 cells was used as a control. Relative quantity of PAR-1 mRNA expression in other four NPC cell lines was calculated using $2^{-\Delta \Delta C t}$ method.

wavelength of $570 \mathrm{~nm}$. Each experiment was performed three times.

Invasion assay in vitro. Transwell chambers (Corning, NY, USA) with 8-mm diameter filters were used in this study. Invasion assay was performed as below. In brief, the ECM gel (Sigma) was diluted to the desired final concentration $(8-12 \mathrm{mg} / \mathrm{ml})$ with cold distilled water. Then $25 \mu \mathrm{g}$ ECM gel was applied to each polyvinylpyrrolidone-free polycarbonate filter and dried under a hood as basement membrane. After that each filter with basement membrane was reconstituted with serum-free medium. In the upper compartment of the transwell chamber, we placed $2 \times 10^{5}$ cells suspended in $0.1 \%$ serum medium with varying doses of thrombin or SFLLRN. Serum medium (30\%) was put into the lower compartment of the transwell chamber as a chemoattractant. Assays were carried out in $5 \% \mathrm{CO}_{2}$ at $37^{\circ} \mathrm{C}$. After $24 \mathrm{~h}$ of incubation, the cells on the upper surface of the filter were removed by wiping with a cotton swab. The filters were fixed with cold methanol and then stained with crystal violet. Cells from five different areas of the lower surface were counted under a microscope at the $\mathrm{x} 200$ objective. Each assay was performed in triplicate.

Gelatin zymography. CNE1-LMP1 cells were cultured in serum-free medium in the absence and presence varying concentrations of thrombin $(0.5,1.0,5.0$ and $10.0 \mathrm{U} / \mathrm{ml})$ or SFLLRN $(10,100,200$ and $300 \mu \mathrm{M})$ for $24 \mathrm{~h}$. Afterward, the supernatants were collected and stored at $-70^{\circ} \mathrm{C}$. The concentration of protein in each group was measured by BCA assay. Gelatin zymography was performed in $10 \%$ SDS-PAGE that had been cast in the presence of $0.1 \%$ gelatin (Sigma). Samples containing $50 \mu \mathrm{g}$ total protein were prepared in non-reducing loading buffer. After electrophoresis, the gels were washed four times with $50 \mathrm{mM}$ Tris- $\mathrm{HCl}, \mathrm{pH} 7.6$, containing $5 \mathrm{mM}$ $\mathrm{CaCl}_{2}, 1 \mu \mathrm{M} \mathrm{ZnCl}_{2}$ and $2.5 \%$ Triton $\mathrm{X}-100$ for 15 min each time, followed by rinsed twice in washing buffer without Triton X-100 for 20 min each time. The gels were then incubated at $37^{\circ} \mathrm{C}$ for $48 \mathrm{~h}$ in $50 \mathrm{mM}$ Tris-HCl buffer containing $5 \mathrm{mM} \mathrm{CaCl}_{2}, 1 \mu \mathrm{M} \mathrm{ZnCl}_{2}$ and $0.02 \%$ Brig-35, $\mathrm{pH}$ 7.6. The

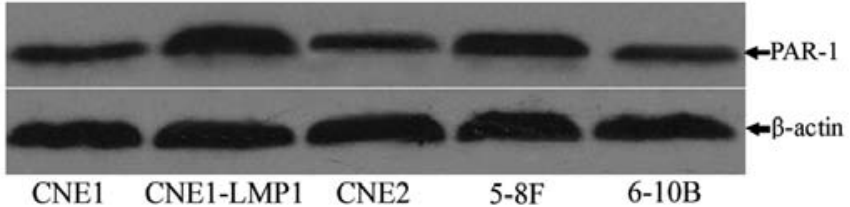

Figure 2. Western blot analysis of PAR-1 protein expression in five NPC cell lines. The $66-\mathrm{kDa}$ PAR-1 was detected by monoclonal antibody against an intact PAR-1. The $42-\mathrm{kDa} \beta$-actin was used as an equal loading control.

digestion was terminated, and the gels were stained with $0.1 \%$ Coomassie Brilliant Blue R-250, followed by destained with $10 \%$ acetic acid and $20 \%$ methanol. Then, the gels were observed by Gel-Pro Analyzer.

Statistical analysis. All results were expressed as mean \pm SD. Statistical analysis was performed using ANOVA with SPSS 15.0 (SPSS 15.0 Inc., Chicago, IL, USA). A P-value $<0.05$ was considered as statistically significant.

\section{Results}

Expression of PAR-1 mRNA in five NPC cell lines. Expression level of PAR-1 mRNA in CNE1 cells was used as a control. Differential expression levels of the PAR-1 mRNA were observed in all five cell lines. As shown in Fig. 1, PAR-1 mRNA in CNE1-LMP1 cells and SUNE1-5-8F cells was significantly higher than that in CNE1 cells $(\mathrm{P}<0.05)$. Compared with SUNE1-6-10B cells, SUNE1-5-8F cells had stronger expression of PAR-1 mRNA $(\mathrm{P}<0.05)$. CNE2 cells and SUNE1-6-10B cells expressed higher PAR-1 mRNA in comparison with CNE1 cells, but there was no significant difference $(\mathrm{P}>0.05)$.

Expression of PAR-1 protein in five NPC cell lines. Next, we detected the expression levels of PAR-1 protein by western blot analysis. As shown in Fig. 2, CNE1-LMP1 cells had the strongest expression of PAR-1 among all five cell lines. SUNE1-5-8F cells demonstrated higher level of PAR-1 expression than SUNE1-6-10B cells. These findings were similar to the results of real-time PCR analysis. Both of them suggested that more invasive and metastatic NPC cell lines expressed more PAR-1. So, we chose CNE1-LMP1 cell line which expressed the highest PAR-1 protein to complete our further research.

Subcellular localization of PAR-1 in nasopharyngeal carcinoma cells. To study the subcellular localization of PAR-1 in cultured NPC cells, indirect immunofluorescence study was performed on CNE1-LMP1 cells using the monoclonal antibody directed against PAR-1. Under such experiment conditions, PAR-1 was labeled with CY3 which lighted red when being excited by laser and the blue region represented the location of nucleus. In this way, the distribution of PAR-1 could be clearly demonstrated. From Fig. 3, we can see receptors are mainly located at the membrane and in the cytoplasm of tumor cells, while little or no distribution in the nucleus. This is in line with other results (32). 


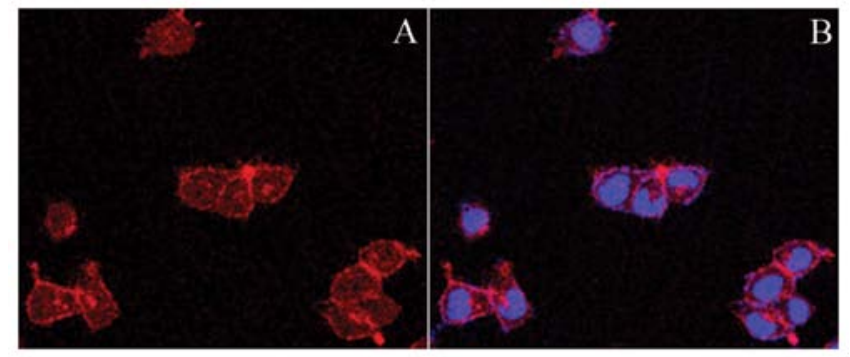

Figure 3. Fluorescent confocal microscope analysis of PAR-1 receptor in CNE1-LMP1 cells with PAR-1 monoclonal antibody and a second CY-3conjugated anti-rabbit IgG. (A) Distribution of PAR-1 protein (red). (B) Distribution of PAR-1 and nuclei (blue).
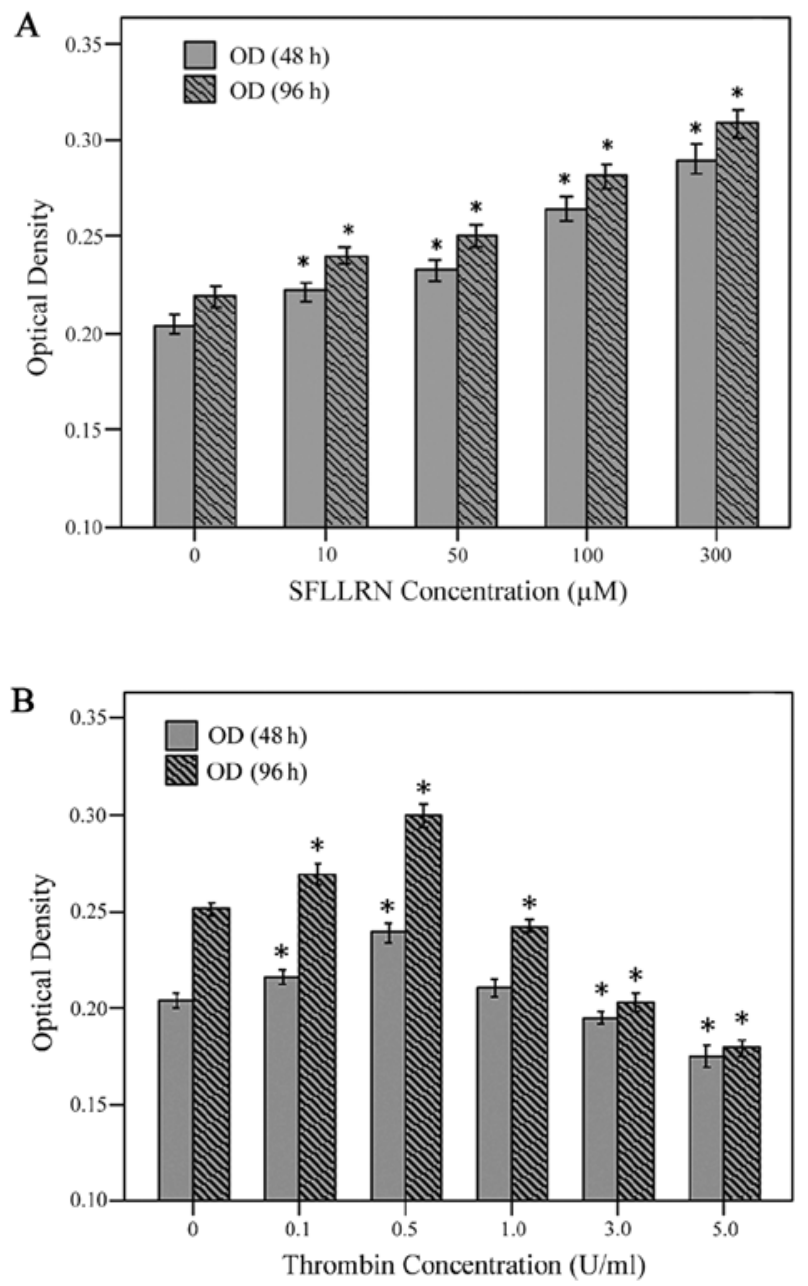

Figure 4. Effect of thrombin or SFLLRN on the growth of CNE1-LMP1. Cells were grown in $1 \%$ serum medium in the absence and presence of thrombin or SRLLRN in different concentrations for 48 or $96 \mathrm{~h}$. Cell proliferation was determined by MTT assay. (A) Effect of SFLLRN on the growth of CNE1-LMP1 cells. (B) Effect of thrombin on the growth of CNE1-LMP1 cells. ${ }^{*} \mathrm{P}<0.05$ compared with control.

Effect of thrombin and SFLLRN on cell proliferation. PAR-1 activation is known to induce proliferation of endothelial cells (33) and a few tumor cell types $(34,35)$. The finding of PAR-1 expression in human NPC cells prompted us to explore the effect of PAR-1 on cell growth. Thrombin and SFLLRN were used as PAR-1 activators. NPC cells were incubated with

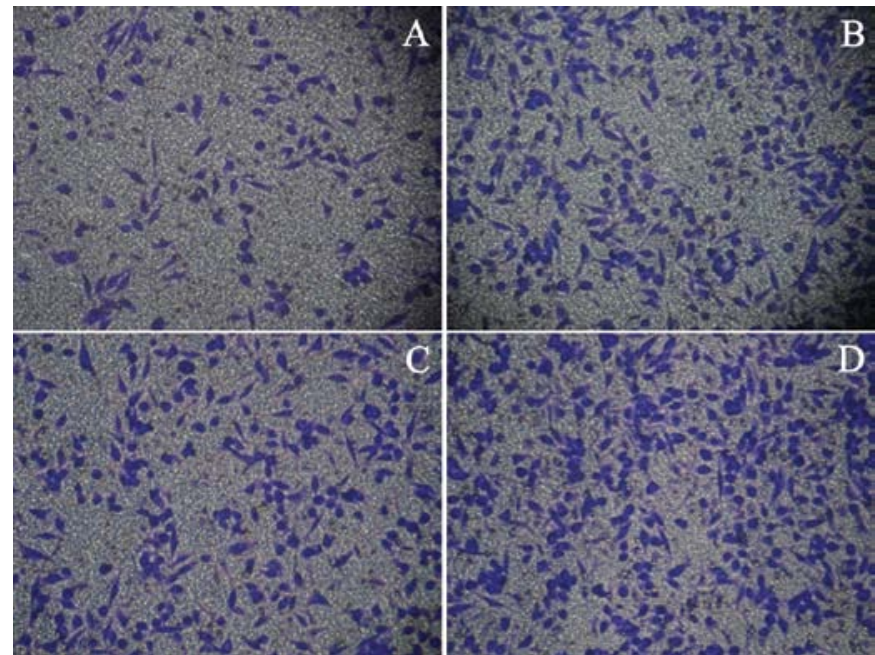

Figure 5. Effect of thrombin and SFLLRN on CNE1-LMP1 cells invasion in vitro. Invasion of CNE1-LMP1 cells toward conditioned medium was measured using transwell chambers with polycarbonate filters coated with ECM gel. And the result was observed under a microscope at the $\mathrm{x} 200$ objective. (A) The control group. (B) CNE1-LMP1 cells treated with $50 \mu \mathrm{M}$ SFLLRN. (C) CNE1-LMP1 cells treated with $0.5 \mathrm{U} / \mathrm{ml}$ thrombin. (D) CNE1-LMP1 cells treated with $5 \mathrm{U} / \mathrm{ml}$ thrombin.

0-300 $\mu$ M SFLLRN either 48 or 96 h. Fig. 4A demonstrated 48 or $96-\mathrm{h}$ exposure of SRLLRN resulted in an increase in cell growth in a dose-dependent manner, and $300 \mu \mathrm{M}$ SFLLRN exerted the most pronounced effect. Thrombin had a dual effect on the proliferation of NPC cells. Concentrations of thrombin in the range of $0.1-0.5 \mathrm{U} / \mathrm{ml}$ promoted cell growth, but concentrations $>0.5 \mathrm{U} / \mathrm{ml}$ impaired cell growth. The inhibitive effect of thrombin on cell growth increased with increasing concentration of thrombin. When the incubation time lasted to $96 \mathrm{~h}$, this dual effect of thrombin on cell proliferation was more obvious (Fig. 4B). All these results suggested that activated PAR-1 might be involved in proliferation of NPC cells.

Effect of thrombin and SFLLRN on cell invasion in vitro. To metastasize, cancer cells must penetrate the extracellular matrix and basement membrane to blood vessel. Therefore, we next investigated the potential role of PAR-1 activators on NPC cells invasion using in vitro invasion assay. After being incubated with CNE1-LMP1 cells for $24 \mathrm{~h}, 50 \mu \mathrm{M}$ SFLLRN, $0.5 \mathrm{U} / \mathrm{ml}$ thrombin and $5 \mathrm{U} / \mathrm{ml}$ thrombin significantly increased invasive ability of cells. Compared with control group, the number of cells which invaded through the basement membrane in three experimental group increased significantly $(\mathrm{P}<0.05)$, of which the most significant group was $5 \mathrm{U} / \mathrm{ml}$ thrombin (Fig. 5).

Effect of thrombin and SFLLRN on MMP-2/9 activation of NPC cells. Matrix metalloproteinases (MMPs) are known to be crucial for degrading extracellular matrix components and for promoting tumor cellular invasion in vitro and in vivo. So, we determined whether the increasing effects of thrombin and SFLLRN on the invasion of CNE1-LMP1 cells were due to enhancing activity of MMP-2 or MMP-9. CNE1-LMP1 cells 
A
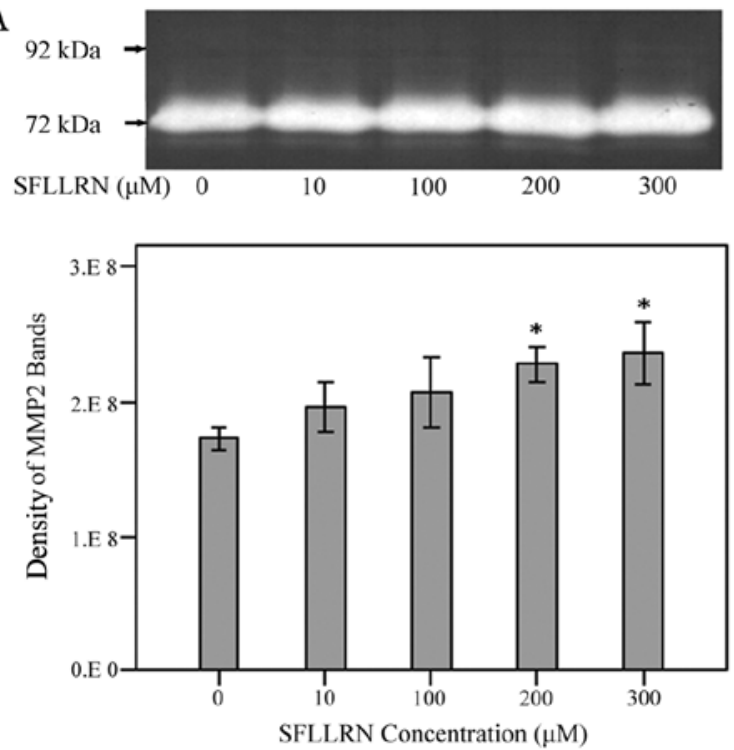

B
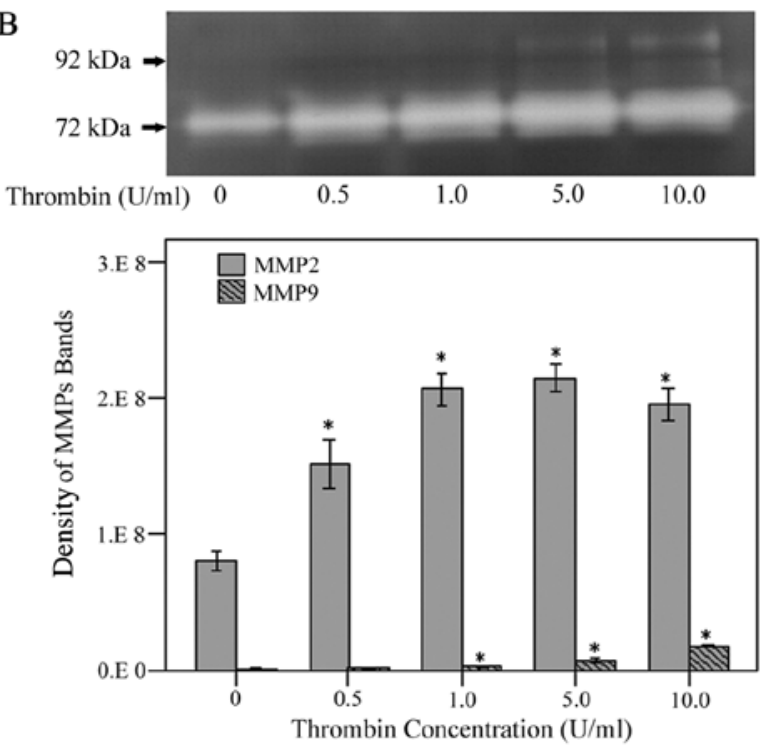

Figure 6. Effect of thrombin and SFLLRN on MMP-2/9 activity of NPC cells by gelatin zymography. The bands of MMP-2 and MMP-9 are in the position of 72 and $92 \mathrm{kDa}$, respectively. Gelatin zymography analysis of MMP-2/9 activity in the supernatant of CNE1-LMP1 cells treated with various concentrations of (A) SFLLRN or (B) thrombin for $24 \mathrm{~h}$. Relative enzyme activities of MMP-2/9 are expressed by analysis of the density of each band. ${ }^{*} \mathrm{P}<0.05$ compared with control.

were treated with various concentrations of SFLLRN and thrombin for $24 \mathrm{~h}$, and then the activities of MMP-2 and MMP-9 in the supernatant of cells were detected using gelatin zymography. As shown in Fig. 6, 0-300 $\mu \mathrm{M}$ SFLLRN had little effect on the activity of MMP-9, and it only had slight effect on the activity of MMP-2 in a dose-dependent manner (Fig. 6A), but thrombin could significantly increase the activities of MMP-2 and MMP-9 in CNE1-LMP1 cells. MMP-2 activity began to increase significantly at the concentration of $0.5 \mathrm{U} / \mathrm{ml}$ thrombin, and was the highest at the concentration of $5 \mathrm{U} / \mathrm{ml}$ thrombin. In the group of control and $0.5 \mathrm{U} / \mathrm{ml}$ thrombin, MMP-9 activity was undetectable, and in the group of $1 \mathrm{U} / \mathrm{ml}$ thrombin we detected very weak MMP-9 activity. However, 5 or $10 \mathrm{U} / \mathrm{ml}$ thrombin enhanced MMP-9 activity greatly (Fig. 6B).

\section{Discussion}

PAR-1 has been found to be highly expressed in the invading cytotrophoblasts and many malignant tissues, and it is involved in cell invasion associated with normal embryonic development and tumor metastasis $(36,37)$. In our study, we determined expression of PAR-1 in five different NPC cell lines and found that all of them expressed PAR-1 which was mainly located at the membrane and in the cytoplasm of tumor cells. Relative quantitative analysis showed that, compared with SUNE1-6-10B and CNE1, there was stronger PAR-1 protein expression in SUNE1-5-8F and CNE1-LMP1 both of which have been demonstrated to be more invasive and metastatic than SUNE1-6-10B and CNE1, respectively. This result suggested that the level of PAR-1 expression was positively correlated with the potential of invasion and metastasis of NPC cells, and PAR-1 might be involved in the invasion and metastasis in NPC. It is noteworthy that PAR-1 expression level in CNE1-LMP1 cells was significantly higher than that in CNE1 cells. Taking previous studies into consideration that LMP1 could induce expression of another membrane protein EGFR in human epithelial cells $(38,39)$, we hypothesized that LMP1 upregulate expression of PAR-1 of NPC cells. However, further study is needed to verify this hypothesis.

Function of PAR-1 in cell proliferation seems to be confusing. Many studies confirmed its role in proliferation of various kinds of normal and malignant cells, probably as a result of upregulation of many cell growth factors and inhibition of cell apoptosis by activating a variety of intracellular signal pathways $(19,40,41)$. However, there were a few studies that demonstrated its negative effect in cancer cell growth $(42,43)$. In our study, we found PAR-1 activators, thrombin and SFLLRN, could induce proliferation of CNE1-LMP1 cells. The effect of SFLLRN on cell growth was dose-dependent, but thrombin had a dual biphasic effect on proliferation of NPC cells. It promoted cell growth at lower concentrations, and impaired cell growth at higher concentrations. This dual effect of thrombin on cell proliferation has also been found in a variety of cancer cells. However, the concentration range of thrombin which promoted or inhibited cell growth was different $(14,43)$. This might be the cause of cell type variations in the PAR-1 level, which consequently affects the signaling transduction network. However, the mechanism how thrombin impaired the cell growth is not yet entirely clear. We speculate that the following partially explain the mechanism. Firstly, when these receptors are activated by either thrombin or SRLLRN, they undergo homologous desensitization and internalization. Most internalized receptors are ultimately degraded in lysosomes, and approximately $25 \%$ of them return to the cell surface. These recycled receptors are in a state in which they can respond to SFLLRN, but not thrombin (44). When the cells are incubated with low concentrations of thrombin, although there are PAR-1 internalized from the cell membrane, the receptors stored in cytoplasm and newly synthesized are transferred to the cell surface to offset the loss of PAR-1. Such a process keeps the PAR-1 levels on the cell surface at a dynamic equilibrium. Thrombin promotes cell proliferation in this condition. When cells are incubated with higher concentrations of thrombin, consumption of PAR-1 is much larger than the regeneration of PAR-1 on the 
cell membrane, which leads to low level of PAR-1 on the cell surface for a long time. This situation is similar to downregulation of PAR-1, which could impair cell proliferation (40). Because SFLLRN can reuse the recycled PAR-1, it does not show inhibition of cell proliferation. Another explanation is that thrombin can cleave the extracellular domain of PAR-1 at three separate sites, Arg41, Arg46 and Arg70, but the activation of the receptor requires only the cleavage at Arg41, while that of the two other sites does not cause receptor activation. Low dose of thrombin produces cleavage at Arg41, while higher dose of thrombin may cleave three sites, thus resulting in less biological effects than low dose of thrombin (45). Interestingly, in non-malignant tissues, the level of prothrombin in serum ranges from 0.1 to $0.5 \mathrm{U} / \mathrm{ml}$ (42), which is exactly the concentration rang of thrombin that enhances the proliferation of NPC cells. Therefore, we deduce that the dual effect of thrombin on NPC cells may be the results of cancer cell adaptation to the internal environment of the human body.

PAR-1 was able to induce invasion of breast cancer cells (46), melanoma cells (47) and gastric cancer cells (48) in vitro, and it was also reported to be a rate-limiting factor in thrombin-enhanced experimental pulmonary metastasis from a mouse melanoma cell line (21). In nasopharyngeal carcinoma, our results indicated that thrombin and SFLLRN could significantly increase invasive ability of CNE1-LMP1 cells. This effect of thrombin might be partly due to increase of MMP-2/9 activities. Further research showed that thrombin could significantly enhance the activities of MMP-2 and MMP-9 in CNE1-LMP1 cells. However, SFLLRN had little impact on the activity of MMP-9, and $50 \mu \mathrm{M}$ SFLLRN only slightly increased the activity of MMP-2. So, SRLLRN might induce NPC cells invasion through another mechanism. For example, it has been reported that PAR-1 activating peptide promoted tumor cells adhesion to extracellular matrix components and then induced invasion of cells (47). The difference of thrombin and SFLLRN on MMPs activities demonstrated other signaling pathway must be responsible for thrombin function in NPC cells. Besides PAR-1, there are other thrombin receptors on cell membrane of many types cells, and thrombin might exert its effect through these receptors $(16,49)$.

In conclusion, our results demonstrated for the first time different expression levels of PAR-1 in nasopharyngeal carcinoma cell lines, and expression level of PAR-1 was positively associated with the metastatic potential of NPC cells. Further research indicated PAR-1 activation contributed to NPC cell proliferation and invasion in vitro, and increased activities of MMP-2 and MMP-9 to some extent. Based on our data and other results that PAR-1 could function as an oncoprotein that transformed fibroblasts in vitro, we speculate that PAR-1 might play an important role in the progression of NPC.

\section{Acknowledgements}

This study was supported by the Natural Science Foundation of Hubei Province (grant no. 2008CBB399).

\section{References}

1. Rickles FR and Edwards RL: Activation of blood coagulation in cancer: Trousseau's syndrome revisited. Blood 62: 14-31, 1983.
2. Lee AY: Cancer and thromboembolic disease: pathogenic mechanisms. Cancer Treat Rev 28: 137-140, 2002.

3. Noble S and Pasi J: Epidemiology and pathophysiology of cancer-associated thrombosis. Br J Cancer 102: S2-S9, 2010.

4. Nierodzik ML and Karpatkin S: Thrombin induces tumor growth, metastasis, and angiogenesis: evidence for a thrombinregulated dormant tumor phenotype. Cancer Cell 10: 355-362, 2006.

5. Coughlin SR: Thrombin signalling and protease-activated receptors. Nature 407: 258-264, 2000.

6. Vu TK, Hung DT, Wheaton VI and Coughlin SR: Molecular cloning of a functional thrombin receptor reveals a novel proteolytic mechanism of receptor activation. Cell 64: 1057-1068, 1991.

7. Nanevicz T, Ishii M, Wang L, et al: Mechanisms of thrombin receptor agonist specificity. Chimeric receptors and complementary mutations identify an agonist recognition site. J Biol Chem 270: 21619-21625, 1995.

8. Elste AP and Petersen I: Expression of proteinase-activated receptor 1-4 (PAR 1-4) in human cancer. J Mol Histol 41: 89-99, 2010.

9. Even-Ram S, Uziely B, Cohen P, et al: Thrombin receptor overexpression in malignant and physiological invasion processes. Nat Med 4: 909-914, 1998.

10. Massi D, Naldini A, Ardinghi C, et al: Expression of proteaseactivated receptors 1 and 2 in melanocytic nevi and malignant melanoma. Hum Pathol 36: 676-685, 2005.

11. Kaushal V, Kohli M, Dennis RA, Siegel ER, Chiles WW and Mukunyadzi P: Thrombin receptor expression is upregulated in prostate cancer. Prostate 66: 273-282, 2006.

12. Darmoul D, Gratio V, Devaud H, Lehy T and Laburthe M: Aberrant expression and activation of the thrombin receptor protease-activated receptor-1 induces cell proliferation and motility in human colon cancer cells. Am J Pathol 162: 1503-1513, 2003.

13. Cisowski J, O'Callaghan K, Kuliopulos A, et al: Targeting protease-activated receptor-1 with cell-penetrating pepducins in lung cancer. Am J Pathol 179: 513-523, 2011.

14. Liu Y, Gilcrease MZ, Henderson Y, Yuan XH, Clayman GL and Chen Z: Expression of protease-activated receptor 1 in oral squamous cell carcinoma. Cancer Lett 169: 173-180, 2001.

15. Ribeiro FS, Simão TA, Amoêdo ND, et al: Evidence for increased expression of tissue factor and protease-activated receptor-1 in human esophageal cancer. Oncol Rep 21: 1599-1604, 2009.

16. Kaufmann R, Junker U, Nuske K, Westermann M, Henklein P, Scheele $J$ and Junker K: PAR-1- and PAR-3-type thrombin receptor expression in primary cultures of human renal cell carcinoma cells. Int J Oncol 20: 177-180, 2002.

17. Boire A, Covic L, Agarwal A, Jacques S, Sherifi S and Kuliopulos A: PAR1 is a matrix metalloprotease-1 receptor that promotes invasion and tumorigenesis of breast cancer cells. Cell 120: 303-313, 2005.

18. Chay $\mathrm{CH}$, Cooper CR, Gendernalik JD, et al: A functional thrombin receptor (PAR1) is expressed on bone-derived prostate cancer cell lines. Urology 60: 60-65, 2002.

19. Tantivejkul K, Loberg RD, Mawocha SC, et al: PAR1-mediated NFkappaB activation promotes survival of prostate cancer cells through a Bcl-xL-dependent mechanism. J Cell Biochem 96: 641-652, 2005.

20. Heider I, Schulze B, Oswald E, Henklein P, Scheele J and Kaufmann R: PAR1-type thrombin receptor stimulates migration and matrix adhesion of human colon carcinoma cells by a PKCepsilon-dependent mechanism. Oncol Res 14: 475-582, 2004.

21. Nierodzik ML, Chen K, Takeshita K, et al: Protease-activated receptor 1 (PAR-1) is required and rate-limiting for thrombinenhanced experimental pulmonary metastasis. Blood 92: 3694-3700, 1998.

22. Martin CB, Mahon GM, Klinger MB, Kay RJ, Symons M, Der CJ and Whitehead IP: The thrombin receptor, PAR-1, causes transformation by activation of Rho-mediated signaling pathways. Oncogene 20: 1953-1963, 2001.

23. Fujimoto D, Hirono Y, Goi T, Katayama K and Yamaguchi A: Prognostic value of protease-activated receptor-1 (PAR-1) and matrix metalloproteinase-1 (MMP-1) in gastric cancer. Anticancer Res 28: 847-854, 2008.

24. Depasquale I and Thompson WD: Prognosis in human melanoma: PAR-1 expression is superior to other coagulation components and VEGF. Histopathology 52: 500-509, 2008. 
25. Hernández NA, Correa E, Avila EP, Vela TA and Pérez VM PAR1 is selectively over expressed in high grade breast cancer patients: a cohort study. J Transl Med 7: 47, 2009.

26. Black PC, Mize GJ, Karlin P, et al: Overexpression of proteaseactivated receptors- $-1,-2$, and -4 (PAR-1, -2 , and -4 ) in prostate cancer. Prostate 67: 743-756, 2007.

27. Peng PH, Wu CC, Liu SC, et al: Quantitative plasma proteome analysis reveals aberrant level of blood coagulation-related proteins in nasopharyngeal carcinoma. J Proteomics 74: 744-757, 2011.

28. Pi GL, Wang T, Wu G, Wu HG, Hu JL, Dai XF and Sun H: Expression of protease-activated recepor-1 in nasopharyngeal carcinoma and its significance. Cancer Res Prev Treat 35: 100-103, 2008 (In Chinese).

29. Gou XM, Chen Y, Chen XY and Arrand JR: Effects of EpsteinBarr virus latent membrane protein 1 (EBV-LMP1) on related factors of metastasis of nasopharyngeal carcinoma cell line CNE1. Ai Zheng 22: 481-485, 2003 (In Chinese).

30. Song LB, Yan J, Jian SW, Zhang L, Li MZ, Li D and Wang HM: Molecular mechanisms of tumorgenesis and metastasis in nasopharyngeal carcinoma cell sublines. Ai Zheng 21: 158-162, 2002 (In Chinese)

31. Livak KJ and Schmittgen TD: Analysis of relative gene expression data using real-time quantitative PCR and the 2(-Delta Delta C(T)) method. Methods 25: 402-408, 2001

32. Kaufmann R, Schafberg H, Rudroff C and Nowak G: Thrombin receptor activation results in calcium signaling and protein kinase C-dependent stimulation of DNA synthesis in HEp-2g laryngeal carcinoma cells. Cancer 80: 2068-2074, 1997.

33. Tsopanoglou NE and Maragoudakis ME: On the mechanism of thrombin-induced angiogenesis. Potentiation of vascular endothelial growth factor activity on endothelial cells by up-regulation of its receptors. J Biol Chem 274: 23969-23976, 1999.

34. Darmoul D, Gratio V, Devaud H, Peiretti F and Laburthe M Activation of proteinase-activated receptor 1 promotes human colon cancer cell proliferation through epidermal growth factor receptor transactivation. Mol Cancer Res 2: 514-522, 2004.

35. Liu J, Bastian M, Kohlschein P, Schuff-Werner P and Steiner M: Expression of functional protease-activated receptor 1 in human prostate cancer cell lines. Urol Res 31: 163-168, 2003.

36. Even-Ram SC, Grisaru-Granovsky S, Pruss D, Maoz M, Salah Z, Yong-Jun Y and Bar-Shavit R: The pattern of expression of protease-activated receptors (PARs) during early trophoblast development. J Pathol 200: 47-52, 2003.

37. Yin YJ, Salah Z, Grisaru-Granovsky S, et al: Human proteaseactivated receptor 1 expression in malignant epithelia: a role in invasiveness. Arterioscler Thromb Vasc Biol 23: 940-944, 2003
38. Miller WE, Earp HS and Raab-Traub N: The Epstein-Barr virus latent membrane protein 1 induces expression of the epidermal growth factor receptor. J Virol 69: 4390-4398, 1995.

39. Thornburg NJ and Raab-Traub N: Induction of epidermal growth factor receptor expression by Epstein-Barr virus latent membrane protein $1 \mathrm{C}$-terminal-activating region 1 is mediated by NF-kappaB p50 homodimer/Bcl-3 complexes. J Virol 81: 12954-12961, 2007.

40. Salah Z, Maoz M, Pokroy E, Lotem M, Bar-Shavit R and Uziely B: Protease-activated receptor-1 (hPar1), a survival factor eliciting tumor progression. Mol Cancer Res 5: 229-240, 2007.

41. Liu J, Schuff-Werner P and Steiner M: Thrombin/thrombin receptor (PAR-1)-mediated induction of IL-8 and VEGF expression in prostate cancer cells. Biochem Biophys Res Commun 343: 183-189, 2006.

42. Huang YQ, Li JJ and Karpatkin S: Thrombin inhibits tumor cell growth in association with up-regulation of p21(waf/cip1) and caspases via a p53-independent, STAT-1-dependent pathway. J Biol Chem 275: 6462-6468, 2000.

43. Zain J, Huang YQ, Feng X, Nierodzik ML, Li JJ and Karpatkin S: Concentration-dependent dual effect of thrombin on impaired growth/apoptosis or mitogenesis in tumor cells. Blood 95 3133-3138, 2000.

44. Hoxie JA, Ahuja M, Belmonte E, Pizarro S, Parton R and Brass LF: Internalization and recycling of activated thrombin receptors. J Biol Chem 268: 13756-13763, 1993.

45. Yoshida E, Verrusio EN, Mihara H, Oh D and Kwaan HC: Enhancement of the expression of urokinase-type plasminogen activator from PC-3 human prostate cancer cells by thrombin. Cancer Res 54: 3300-3304, 1994.

46. Arora P, Cuevas BD, Russo A, Johnson GL and Trejo J: Persistent transactivation of EGFR and ErbB2/HER2 by protease-activated receptor-1 promotes breast carcinoma cell invasion. Oncogene 27: 4434-4445, 2008.

47. Even-Ram SC, Maoz M, Pokroy E, Reich R, Katz BZ, Gutwein P, Altevogt $\mathrm{P}$ and Bar-Shavit R: Tumor cell invasion is promoted by activation of protease activated receptor-1 in cooperation with the alpha vbeta 5 integrin. J Biol Chem 276: 10952-10962, 2001.

48. Fujimoto D, Hirono Y, Goi T, Katayama K, Matsukawa S and Yamaguchi A: The activation of proteinase-activated receptor-1 (PAR1) mediates gastric cancer cell proliferation and invasion. BMC Cancer 10: 443, 2010.

49. Kaufmann R, Rahn S, Pollrich K, et al: Thrombin-mediated hepatocellular carcinoma cell migration: cooperative action via proteinase-activated receptors 1 and 4 . J Cell Physiol 211: 699-707, 2007 